\title{
STUDY OF THE INFLUENCE OF THE ENERGOINFROMATIONAL FIELD ON QUALITY OF THE FUEL APPLIED IN INTERNAL COMBUSTION ENGINES OF ROAD-BUILDING MACHINERY
}

\author{
Ravil Safiullin ${ }^{1}$, Mukhtar Kerimov ${ }^{2}$, Aleksander Afanasyev ${ }^{3}$ \\ 1,2 Saint Petersburg State University of Architecture and Civil Engineering \\ Vtoraja Krasnoarmejskaja ul. 4, St. Petersburg, Russia \\ ${ }^{3}$ Saint Petersburg Mining University \\ 21st Line, 2, St. Petersburg, Russia \\ ${ }^{1}$ safravi@mail.ru
}

\section{Abstract}

Directions for the improvement of the performance of road-building machinery and transportation vehicles, as well as technological properties of fuels are considered. A model for the improvement of road-building machinery performance when using fuels of various physical and chemical composition is developed.

The specified model includes a system of immediate fuel quality assessment. Experimental studies were carried out in order to determine the influence of the energoinformational field produced by the Kozyrev heavy particles generator on fuel performance characteristics.

The obtained results show a decrease in fuel consumption by internal combustion engines of road-building machinery concurrently with changes in the harmful substance concentration in exhaust gases.

Recommendations for calibration of electronic systems of internal combustion engines are elaborated.

\section{Keywords}

Technology level, motor fuel, energoinformational field, performance, integrated assessment, road-building machinery.

\section{Introduction}

With the development of regional construction and transportation industries, the number of road-building machines and vehicles, being sources of the formation of technical services and main consumers of fuel and energy resources, increases. The transportation work load increases as well. Modern road-building machinery becomes more complex, equipped with various innovative electronic and telematic systems. We face a crucial task to increase the service life of internal combustion engines (ICE) due to a decrease in their calorific intensity. Increasingly strict requirements on the assurance of energy efficiency and environmental safety are imposed upon ICE. As a result, we encounter a problematic situation where the adequate and prompt solution of this problem depends largely on the implemented means and methods. The achievement of the stated objective through the development of new ICE types during a short period of time seems to be impossible in terms of design and economically impractical (Safiullin, and Kerimov, 2014a, 2014b). Therefore, the rational use of fuel by means of fuel composition optimization concurrently with the improvement of ICE design based on intelligent on-board systems represents a scientific problem of academic and practical interest.

\section{Methods}

The fuel quality level is a relative value based on the comparison of values characterizing technological and environmental maturity of complex indicators of the assessed fuel. At the present time, quality is becoming a "control object". In other words, we refer to the development of a quality optimization system, quality planning, control and regulation during operation of road-building 
machinery ICE (Safiullin and Kerimov, 2014c, 2014d; Denisov, 1998).

The quality level mostly depends on technological methods affecting fuel, technological intensity and controllability of the implemented process, efficiency of ICE electronic modules and ICE adaptational and organizational level (Figure 1).

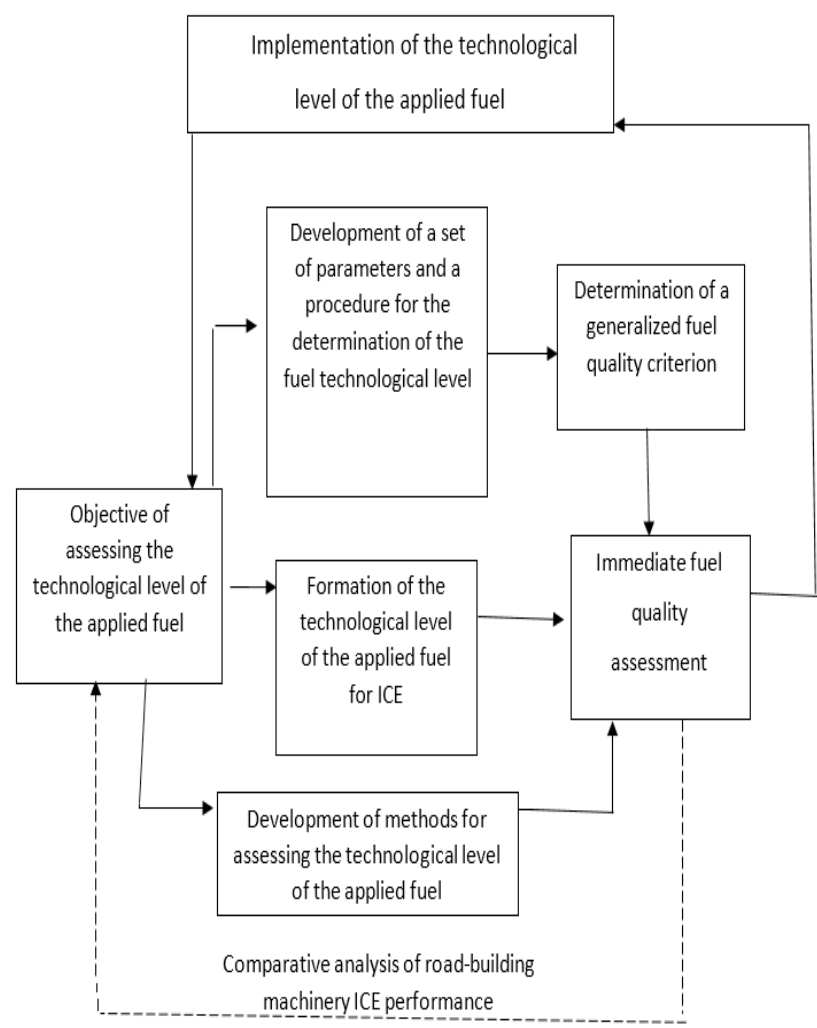

Figure 1. Model of influence of the technological level of the applied fuel on road-building machinery performance

The experimental studies were continued in order to determine the influence of the energoinformational field produced by the Kozyrev heavy particles generator (KHPG) on fuel performance characteristics. A KHPG is a centrifuge and vortex device forming a vertical flux of particles, changing the space structure (Denisov, 1975,

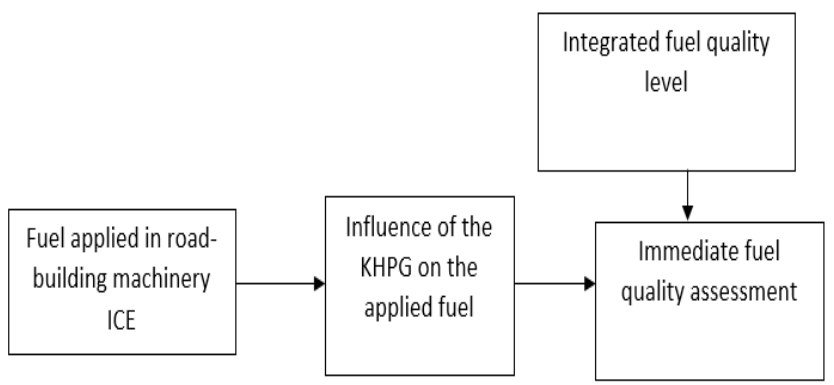

Figure 2. Flow chart of fuel quality formation under the influence of the KHPG
1998). The process of fuel quality formation under the influence of the KHPG is presented in Figure 2.

The experimental studies were carried out in the Transportation Energy laboratory of the Automobile and Road-Building Department of the Saint Petersburg State University of Architecture and Civil Engineering on a test bench equipped with the VAZ-2112 engine with a 5-speed manual transmission. Engine operation control is carried out using an automated system for the control of the data on the transportation vehicle ICE technical condition (Safiullin, 2017) concurrently with the control of the loading device.

The determination of the gasoline fraction composition was carried out using the ARN-LAB-03 device for the distillation of oil products. The recording of changes in fuel performance characteristics was carried out using the ShatoxSX300 device for the determination of the knock characteristic of gasolines, hypergolicity of diesel fuels based on the measurement of their dielectric permittivity and specific volume resistivity. The study procedure provides for the implementation of the following actions.

Table 1. Sequence of studies on the influence of the energoinformational field on performance characteristics of fuels

\begin{tabular}{|c|l|}
\hline $\begin{array}{c}\text { Experi- } \\
\text { ment }\end{array}$ & \\
\hline 1 & $\begin{array}{l}\text { 1. Determination of the fraction composition of } \\
\text { non-modified gasoline using a device for the determi- } \\
\text { nation of the fraction composition of oil products. } \\
\text { 2. Recording of the data on performance characteris- } \\
\text { tics of non-modified gasoline using the ShatoxSX300 } \\
\text { device. }\end{array}$ \\
\hline 2 & $\begin{array}{l}\text { 1. Influence of the KHPG on the applied gasoline } \\
\text { during } 60 \text { minutes. } \\
\text { 2. Determination of the fraction composition of modified } \\
\text { gasoline using a device for the determination of the } \\
\text { fraction composition of oil products. } \\
\text { 3. Recording of the data on performance character- } \\
\text { istics of modified gasoline using the ShatoxSX300 } \\
\text { device. }\end{array}$ \\
\hline 3 & $\begin{array}{l}\text { 1. Determination of the fraction composition of } \\
\text { non-modified diesel fuel using a device for the determi- } \\
\text { nation of the fraction composition of oil products. } \\
\text { 2. Recording of the data on performance characteris- } \\
\text { tics of non-modified diesel fuel using the ShatoxSX300 } \\
\text { device. }\end{array}$ \\
\hline 4 & $\begin{array}{l}\text { 1. Influence of the KHPG on the applied diesel fuel } \\
\text { during } 60 \text { minutes. } \\
\text { 2. Determination of the fraction composition of modified } \\
\text { diesel fuel using a device for the determination of the } \\
\text { fraction composition of oil products. } \\
\text { 3.Recording of the data on performance characteristics } \\
\text { of modified diesel fuel using the ShatoxSX300 device }\end{array}$ \\
\hline
\end{tabular}




\section{Main body}

Due to the fact that the technological system is implemented under the action of random factors, values of all individual indicators of fuel quality are also random. Therefore, the integrated assessment of probabilistic characteristics of these values serves as an indicator of the efficiency of such technological system.

A model for the improvement of road-building machinery performance when using fuels of various physical and chemical composition, including the fuel quality assessment system (FQAS) presented in Figure 3, is developed.

The specified system allows for quick changes in fuel metering, ignition dwell angle and other ICE adjustment parameters in all operation modes. It also allows informing the driver of the improper fuel composition leading to a breakdown. After the combination of physical properties of fuels according to the level of the influence on road-building machinery performance, we will obtain the following three groups:

- indicators characterizing energetic properties;

- indicators characterizing carburetion characteristics;

- indicators characterizing fuel contamination.

An integrated approach to fuel quality level assessment based on the application of a weighted average is taken as the basis for the procedure being developed. For this purpose, the following equation is used (Safiullin and Kerimov, 2014d):

$$
\begin{aligned}
& \mathrm{N}=A_{x} B_{y} C_{z} \iiint_{D} \alpha_{x} d x d y d z= \\
& =\psi_{0} \iiint_{D} \alpha_{y} d x d y d z=\psi_{01} \iiint_{D} \alpha_{z} d x d y d z
\end{aligned}
$$

where: $\alpha_{x}$ is a group quality indicator characterizing performance characteristics of fuel; $\alpha_{y}$ is an integrated quality indicator characterizing performance characteristics of fuel; $\alpha_{z}$ are individual quality indicators obtained upon fuel testing; $A_{x}$ is a weight coefficient of an $i$-th group quality indicator; $B_{y}$ is a weight coefficient of an $i$-th integrated quality indicator; $C_{z}$ is a weight coefficient of an $i$-th individual quality indicator; $\psi_{c}$ is a weight coefficient of certain quality indicators; $D$ is a range of values of quality indicators characterizing fuel of a particular type, regulated by standards.

A relationship between fuel characteristics and its electrical and physical parameters, in particular, dielectric permittivity (DP) $\Omega$, is included in the fuel quality assessment system. Figure 3 presents the results of studies on

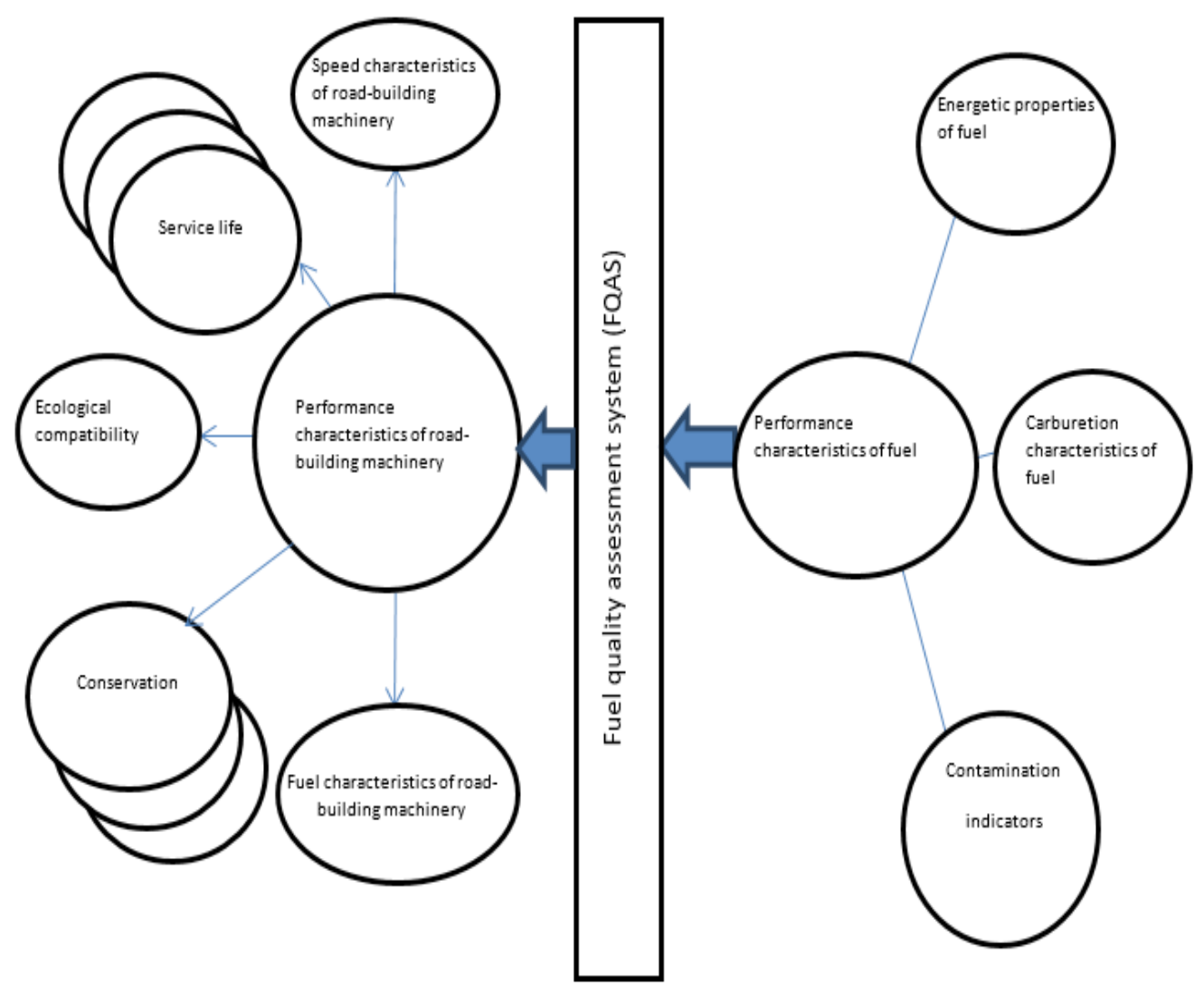

Figure 3. Model for the improvement of road-building machinery performance when using fuels of various physical and chemical composition 


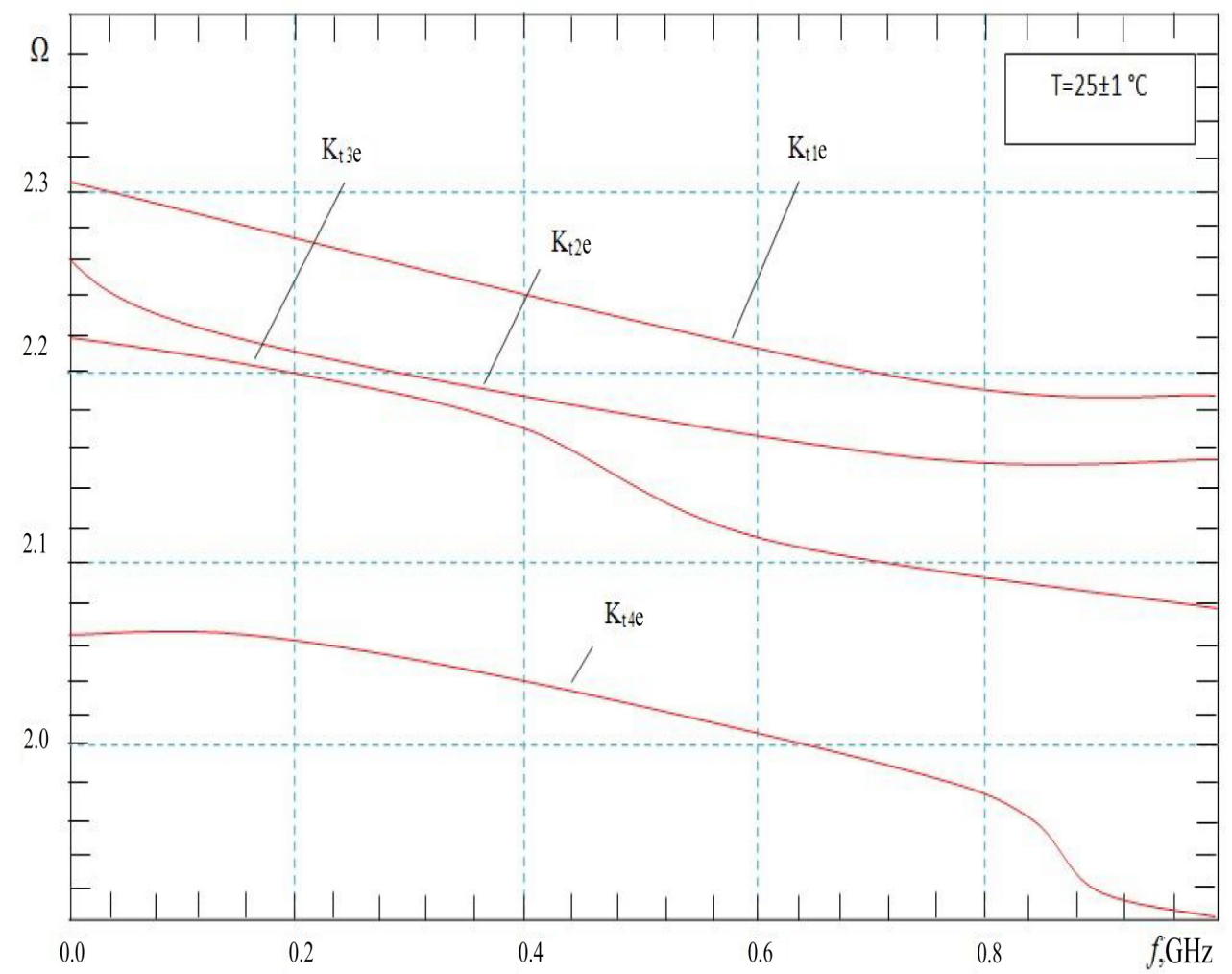

Figure 4. Results of the study on DP real part values for fuels based on WFE and conventional diesel fuel on various frequencies at a constant temperature

DP of fuels from Faeton, Neste, PTK (Saint Petersburg) filling stations on various frequencies at a constant temperature. According to the results, fuels of different quality have different values of dielectric permittivity on different frequencies. Therefore, we can conclude that the set of the data on DP values can be used for the qualitative assessment of fuels (Safiullin and Kerimov, 2014c, 2014d).

\section{Results of the study}

According to the results of the study on dielectric permittivity of fuels, the values of characteristics of diesel fuel based on water-fuel emulsion (WFE) are several-fold larger than the same values of conventional fuels. Figure 4 presents diagrams of DP real part values on various frequencies for 4 clusters corresponding to four identified groups of fuels: $K_{t 4}$ - fuel L-0,2 GOST 305-82, $K_{t 3}, K_{t 2}$, $\mathrm{K}_{\mathrm{t} 1}$ - WFE with water content of 5,10 and $20 \%$ by mass, respectively.

As a result of the processing of the experimental data, regression equations were obtained: the first one corresponds to a group of fuels with a low value of Kt (groups 1 and 2), and the second one corresponds to group 3 (Safiullin and Kerimov, 2014c, 2014d):

$$
K t_{1}=-164.54+260.407 \times \Omega-89.53 \times \Omega^{2}+12,793 \times \Omega^{3}-0.65 \times \Omega^{4}
$$

$$
\begin{aligned}
& K t_{2 e}=-1230+897 \times \Omega-67.55 \times \Omega^{2}+12.793 \times \Omega^{3} \\
& K t_{3 e}=-3561.3+3494.64 \times \Omega-835.55 \times \Omega^{2}
\end{aligned}
$$

To assess the technological level of fuel, 3 subsets were composed: the first and the second subsets include samples of diesel fuel with a rather low value of $K_{t 1}, 2$ corresponding to WFE with water content of $5,10 \%$ by mass (curves 1, 2, Figure 5), and the third value of $\mathrm{K}_{\mathrm{t} 3}$ includes fuel based on WFE with water content of $20 \%$ by mass (curve 3, Figure 5). The testing of the obtained models, which was carried out using the fuels not included into the sample group, has shown that the error in values of the generalized fuel quality criterion Kt with regard to the samples does not exceed the permissible level. To calculate the fuel quality criterion $\mathrm{K}_{\mathrm{t}}$, the following sequence of operations shall be performed:

- receipt of a polymetric signal;

- primary signal processing in order to reduce the interference effect;

- calculation of parameters in the time domain: delays between pulses, pulse amplitudes, fuel level calculation, determination of DP and fuel utilization coefficient values;

- assessment of fuel affiliation with one of the groups identified during cluster analysis; 


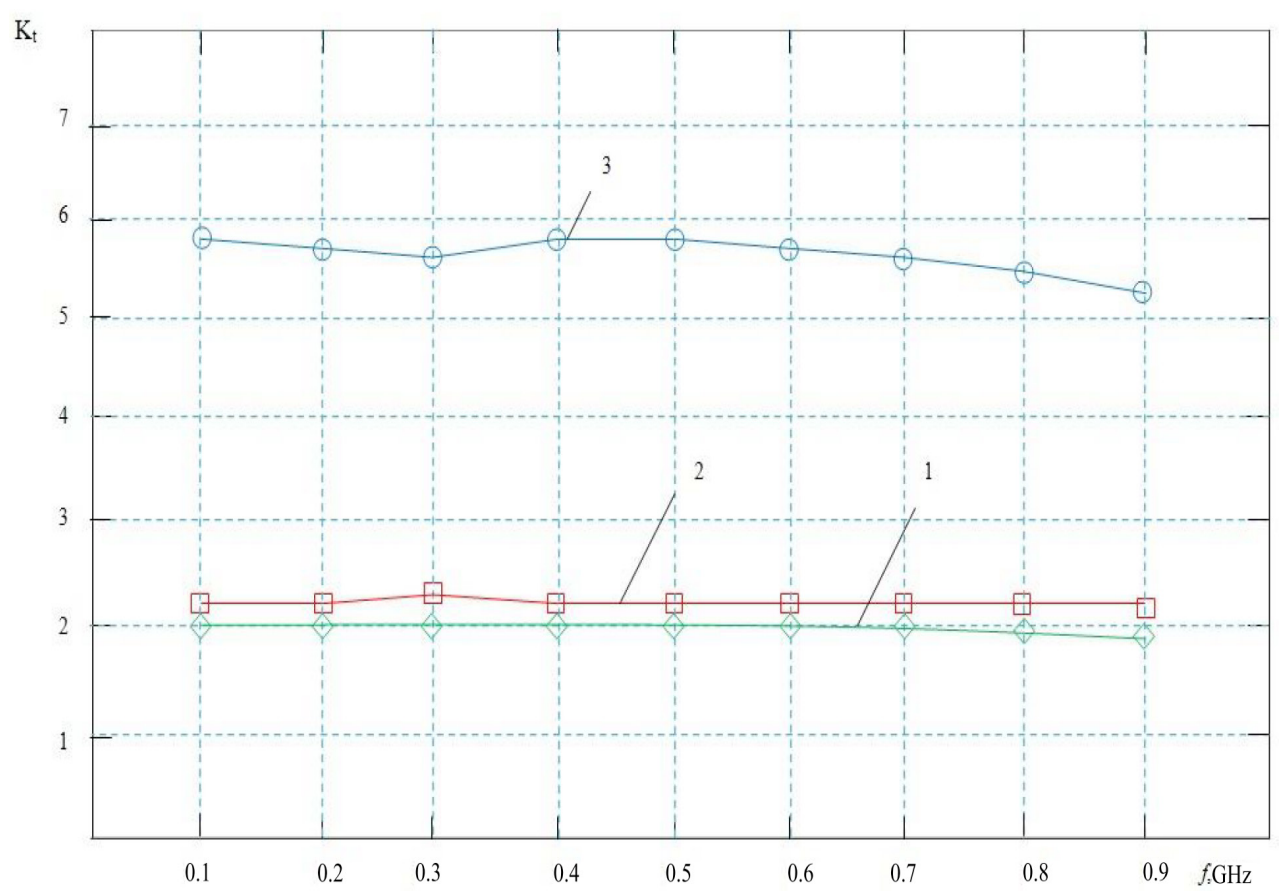

Figure 5. Results of the study on quality of fuels based on WFE with water content of 5,10 and $20 \%$ by mass according to DP on various frequencies and at a constant temperature

- fuel quality assessment according to the value of the fuel utilization coefficient depending on the chosen group.

To improve quality assessment accuracy, it is proposed to identify a class (group) of the studied fuel automatically based on the information on the value of its complex DP on various frequencies. The preliminary division of fuels into groups is performed based on the cluster analysis of the experimental data on fuel utilization coefficient values on various frequencies. It allows applying fuel quality assessment systems upon real-time monitoring of fuel parameters directly in ICE.

The obtained results are presented in Tables $2-6$ as well as in Figures 6-8.

Table 2. Fraction composition of non-modified and modified gasoline (experiment 1 )

\begin{tabular}{|c|c|c|}
\hline Fraction (\%) & $\mathrm{t}$ (non-modified) & $\mathrm{t}$ (modified) \\
\hline 0 & 38 & 42 \\
\hline 5 & 45 & 51 \\
\hline 10 & 50 & 56 \\
\hline 15 & 54 & 57 \\
\hline 20 & 58 & 57 \\
\hline 30 & 66 & 62 \\
\hline 40 & 77 & 69 \\
\hline 50 & 88 & 81 \\
\hline 60 & 104 & 104 \\
\hline 70 & 119 & 120 \\
\hline 80 & 138 & 138 \\
\hline 90 & 160 & 154 \\
\hline 95 & 125 & 168 \\
\hline
\end{tabular}

Table 3. Performance characteristics of the SX300 gasoline (experiment 2)

\begin{tabular}{|c|c|c|}
\hline Parameter & Non-modified & Modified \\
\hline Oct(RON) & 96.7 & 96.6 \\
\hline Oct(MON) & 87.1 & 87.0 \\
\hline Tbd & 1,601 & 1,695 \\
\hline $\mathrm{Eps}(\mathrm{U})$ & 2.2259 & 2.2152 \\
\hline $\mathrm{Eps}(\mathrm{P})$ & 3.1885 & 3.1796 \\
\hline $\mathrm{Kw}$ & $0.4 \%$ & $0.3 \%$ \\
\hline Oct+Ad & $0.01 \%$ & $0.00 \%$ \\
\hline $\mathrm{ON}$ & 3.6 & $0 \%$ \\
\hline $\mathrm{p}$ & $6.74^{*} 10^{-16}$ & $6.49^{*} 10^{-16}$ \\
\hline $\mathrm{p}$ & 0.733 & 0.739 \\
\hline
\end{tabular}

Table 4. Performance characteristics of diesel fuel (experiment 4)

\begin{tabular}{|c|c|c|}
\hline Parameter & Modified & Non-modified \\
\hline Cet & 51.1 & 50.5 \\
\hline $\mathrm{t}($ freezing) & -10.2 & -11.4 \\
\hline $\mathrm{Eps}(\mathrm{U})$ & 2.2159 & 2.2199 \\
\hline $\mathrm{Eps}(\mathrm{P})$ & 3.1085 & 3.1368 \\
\hline $\mathrm{Kw}$ & $0 \%$ & $0.4 \%$ \\
\hline $\mathrm{p}$ & $3.36^{*} 10^{-12}$ & $3.38^{*} 10^{-12}$ \\
\hline $\mathrm{p}$ & 0.829 & 0.827 \\
\hline
\end{tabular}


Table 5. Determination of the fraction composition of non-modified and modified diesel fuel (experiment 3)

\begin{tabular}{|c|c|c|}
\hline Fraction (\%) & $\mathrm{t}$ (non-modified) & $\mathrm{t}$ (modified) \\
\hline 0 & 172 & 174 \\
\hline 5 & 188 & 190 \\
\hline 10 & 201 & 202 \\
\hline 15 & 209 & 211 \\
\hline 20 & 217 & 218 \\
\hline 30 & 237 & 235 \\
\hline 40 & 254 & 250 \\
\hline 50 & 265 & 260 \\
\hline 60 & 277 & 275 \\
\hline 70 & 289 & 289 \\
\hline 80 & 313 & 310 \\
\hline 90 & 327 & 330 \\
\hline 95 & 334 & 347 \\
\hline
\end{tabular}

Eps $(U)$ - dielectric permittivity (pouring)

Eps $(P)$ - dielectric permittivity (submerging)

$K w$ - water content, \%

$p$ - volume resistivity, Ohm $\cdot \mathrm{m}$

$p$ - density, $\mathrm{kg} / \mathrm{m}^{3}$

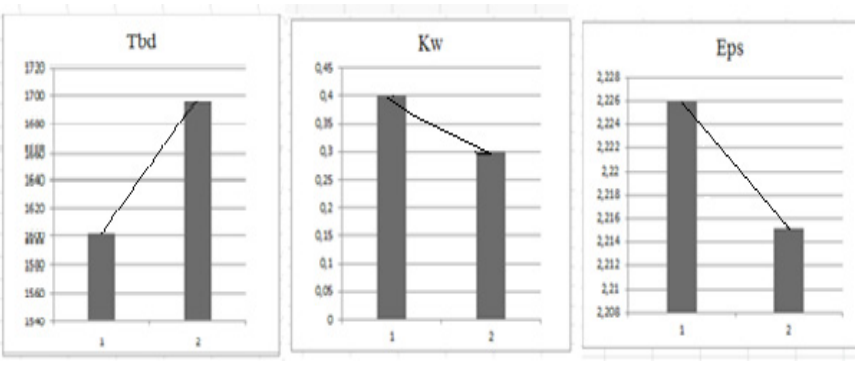

Figure 6. Influence of the KHPG vortex effect on the octane number, water content, induction period of oxidation and dielectric permittivity of gasoline

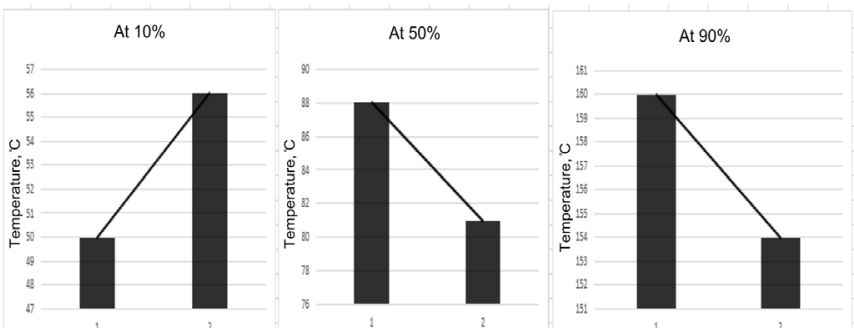

Figure 7. Influence of the KHPG vortex effect on the starting (at $10 \%$ ), power (at $50 \%$ ) and tail (at $90 \%$ ) fractions of gasoline

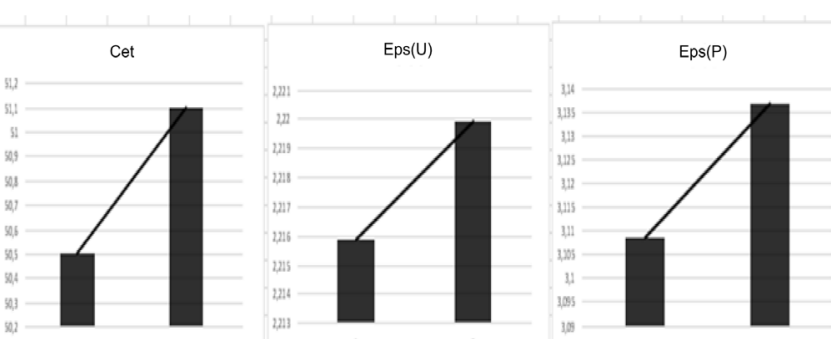

Figure 8. Influence of the KHPG vortex effect on the cetane number and dielectric permittivity of diesel fuel ( 1 - modified, 2 - non-modified)

According to the performed studies, changes in the parameters characterizing hourly consumption and performance characteristics depending on the KHPG influence on gasoline were established (Figures 5-10).

Under the influence of the KHPG, the temperature of distillation of $50 \%$ of gasoline decreases, which has positive effect on engine warm-up intensity, stability of its performance at a low crankshaft speed, as well as acceleration time (Safiullin, 2017; Hilliard, 1988; Makerle, 1987; Safiullin and Kerimov, 2016).

According to the results of the preliminary experimental studies, the temperature of medium gasoline fraction boil-off decreases significantly (by 7-10\%), which has positive effect on ICE performance due to smoother entering of the fuel-air mixture of the required composition to the cold engine. The decrease in the temperature of distillation of $90 \%$ of gasoline indicates the increase in fuel-air mixture combustion intensity and efficiency as well as engine power.

The results of the KHPG influence on fuel and environmental characteristics of ICE are presented in Table 6.

Accepted designations:

FREQ - readings of the engine crankshaft rpm sensor, rpm;

JAIR — air-mass flow, $\mathrm{kg} / \mathrm{h}$;

JGBC - amount of fuel injected into the engine cylinder per 1 stroke, mg/stroke;

JQT — fuel consumption, $\mathrm{kg} / \mathrm{h}$;

THR — throttle position, \%;

INJ - injection time, ms;

TWAT - coolant temperature, ${ }^{\circ} \mathrm{C}$

$\mathrm{CO}-\mathrm{CO}$ volume content in exhaust gases, \%

$\mathrm{CO}_{2}-\mathrm{CO}_{2}$ volume content in exhaust gases, $\%$

$\mathrm{HC}-\mathrm{CH}$ volume content in exhaust gases, \%

$\mathrm{O}_{2}-\mathrm{O}_{2}$ volume content in exhaust gases, \%

NOx - NOx volume content in exhaust gases, \%

Diagrams showing the KHPG influence on fuel (Figure 9) and environmental characteristics (Figure 10) of ICE performance are constructed based on the obtained data. 


\section{Architecture and Engineering Volume 2 Issue 4}

Table 6. Results of the KHPG influence on fuel and environmental characteristics of ICE in experimental studies

\begin{tabular}{|c|c|c|c|c|c|c|c|c|c|c|}
\hline \multirow[t]{2}{*}{ Parameter } & \multicolumn{10}{|c|}{ Values } \\
\hline & $\begin{array}{l}\text { Without } \\
\text { KHPG }\end{array}$ & $\begin{array}{c}\text { After } \\
\text { KHPG } \\
\text { action }\end{array}$ & $\begin{array}{l}\text { Without } \\
\text { KHPG }\end{array}$ & $\begin{array}{c}\text { After } \\
\text { KHPG } \\
\text { action }\end{array}$ & $\begin{array}{l}\text { Without } \\
\text { KHPG }\end{array}$ & $\begin{array}{c}\text { After } \\
\text { KHPG } \\
\text { action }\end{array}$ & $\begin{array}{l}\text { Without } \\
\text { KHPG }\end{array}$ & $\begin{array}{c}\text { After } \\
\text { KHPG } \\
\text { action }\end{array}$ & $\begin{array}{c}\text { Without } \\
\text { KHPG }\end{array}$ & $\begin{array}{c}\text { After } \\
\text { KHPG } \\
\text { action }\end{array}$ \\
\hline FREQ rpm & 1,040 & 1,040 & 1,800 & 1,840 & 2,240 & 2,200 & 2,480 & 2,520 & 2,880 & 2,800 \\
\hline JAIR kg/h & 18.4 & 14.6 & 24.7 & 21 & 31.5 & 24.9 & 33.1 & 27.6 & 40.9 & 33.9 \\
\hline $\begin{array}{l}\text { JGBC mg/ } \\
\text { stroke }\end{array}$ & 150 & 123.3 & 115.3 & 98.67 & 116.7 & 95.33 & 110.7 & 94.67 & 113.3 & 98.67 \\
\hline $\mathrm{JQT} \mathrm{kg} / \mathrm{h}$ & 1.7 & 1.4 & 2.2 & 1.9 & 2.8 & 2.2 & 2.9 & 2.5 & 3.5 & 2.9 \\
\hline THR \% & 0 & 3 & 2 & 5 & 3 & 5 & 4 & 6 & 5 & 7 \\
\hline INJ ms & 3.4 & 2.85 & 2.69 & 2.41 & 2.81 & 2.34 & 2.73 & 2.41 & 2.81 & 2.42 \\
\hline${ }^{T W A T}{ }^{\circ} \mathrm{C}$ & 90 & 90 & 95 & 91 & 101 & 91 & 99 & 99 & 99 & 95 \\
\hline $\mathrm{CO}, \%$ & 0.09 & 0.03 & 0.04 & 0.11 & 0 & 0.11 & 0 & 0.08 & 0 & 0.02 \\
\hline $\mathrm{CO} 2, \%$ & 13.8 & 13.1 & 14.2 & 13.8 & 13.4 & 13.5 & 13.5 & 13.7 & 13.5 & 13.8 \\
\hline $\mathrm{HC}, \%$ & 87 & 88 & 77 & 87 & 49 & 77 & 38 & 65 & 30 & 44 \\
\hline O2, \% & 2.73 & 1.36 & 2.59 & 1.36 & 2.73 & 1.36 & 2.73 & 1.36 & 2.73 & 1.5 \\
\hline NOx, \% & 1.13 & 1.067 & 1.122 & 1.061 & 1.14 & 1.062 & 1.139 & 1.063 & 1.139 & 1.073 \\
\hline
\end{tabular}
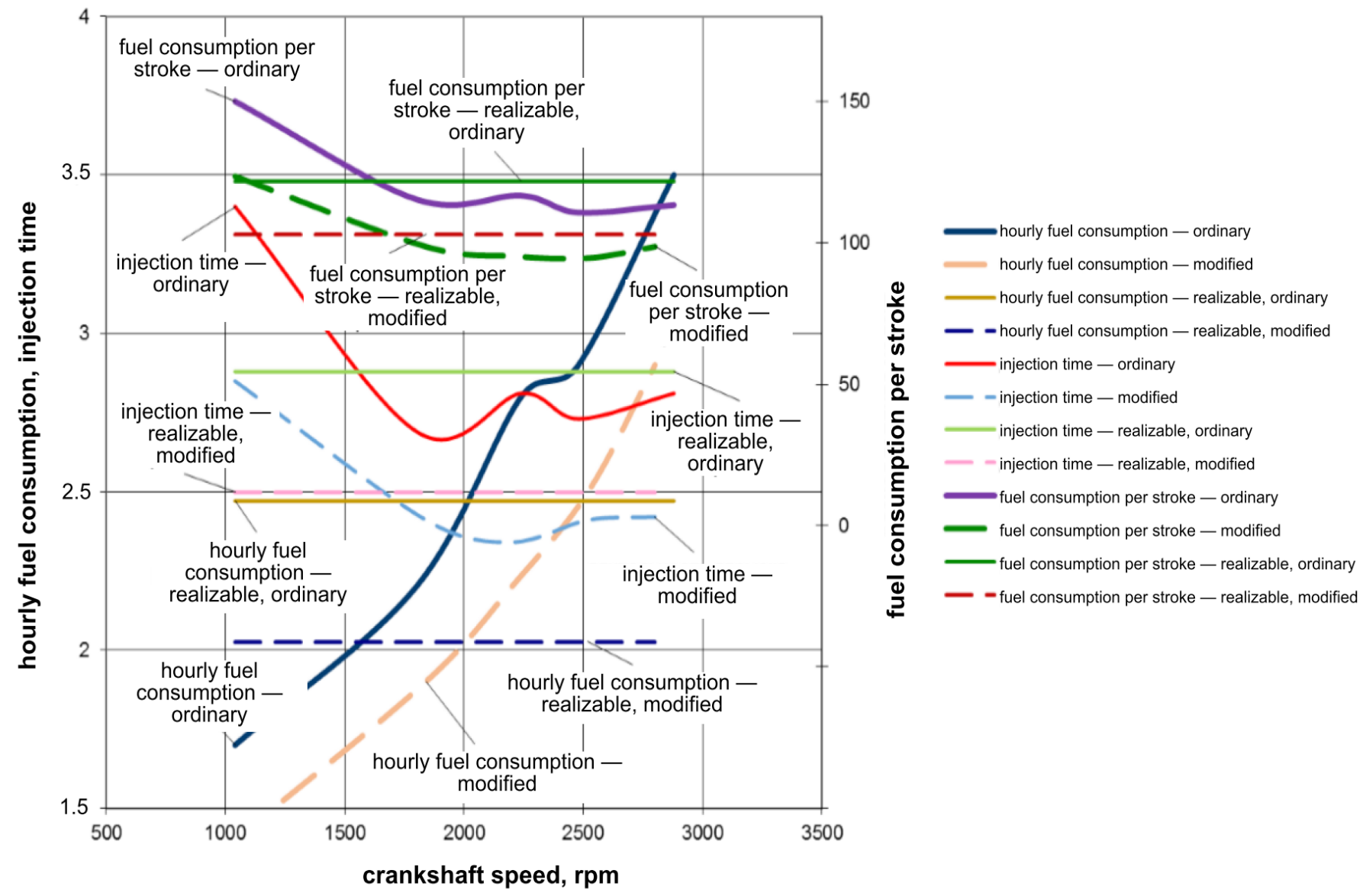

Figure 9. Fuel-efficient characteristics of ICE when using the KHPG 


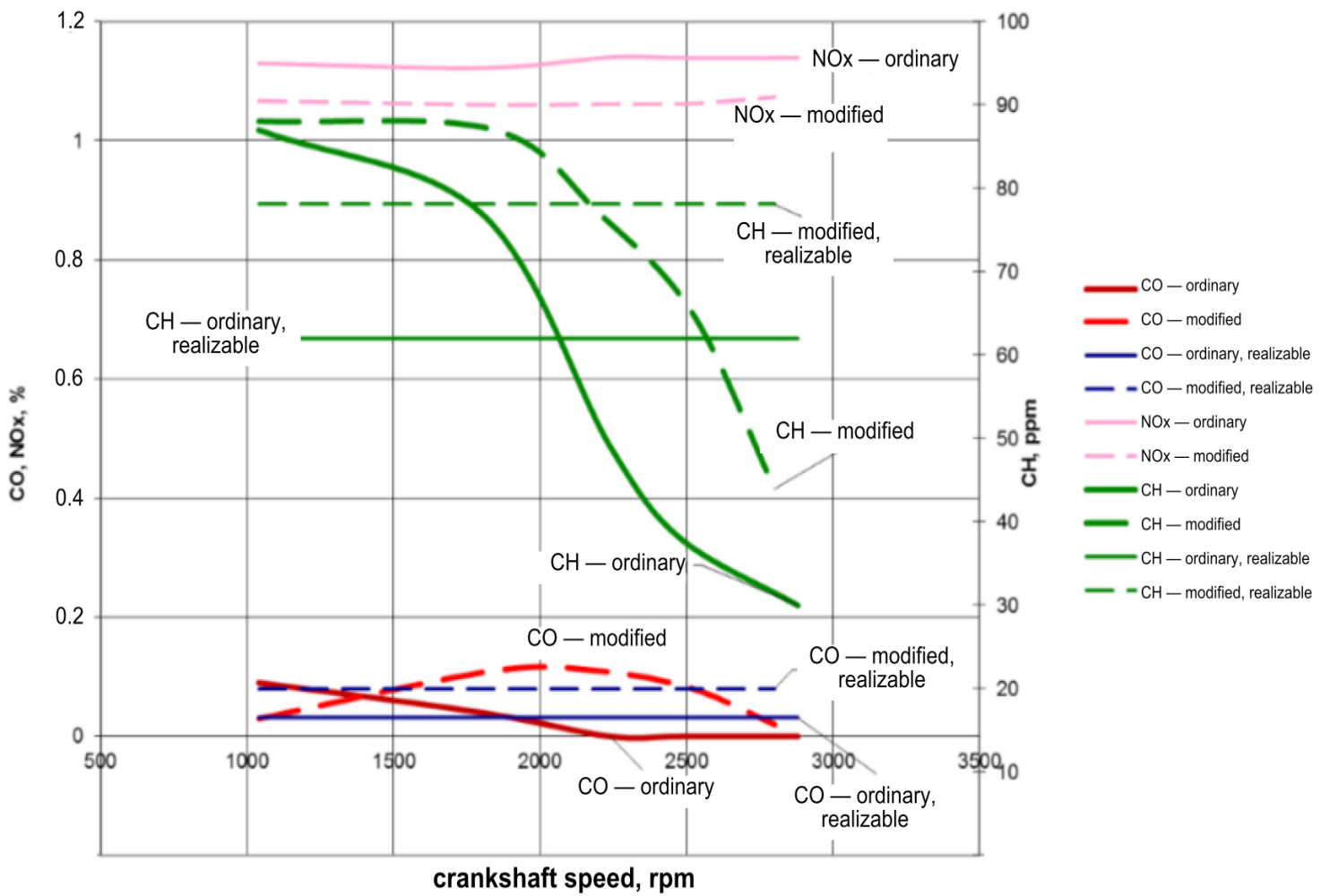

Figure 10. Environmental characteristics of ICE when using the KHPG

\section{Conclusions}

A theoretical basis for the formation of the technological level of the applied fuel in road-building machinery ICE are developed based on the carried-out studies. A physical model for studies of the influence of the technological level of the applied fuel on the performance of road-building machinery, transportation vehicles and equipment is proposed.

According to the results of the experimental studies on the KHPG influence on motor fuel, the following preliminary conclusions can be drawn:

1. Changes in the parameters characterizing fuel consumption and performance characteristics depending on the KHPG influence on gasoline were established (Figures 9-10):

- decrease in the ICE temperature at the same loads (up to $20 \%$ );

- decrease in fuel consumption (up to $20 \%$ );

- decrease in oxygen concentration in exhaust gases (up to $50 \%$ );

- decrease in nitrogen oxide concentration in exhaust gases (up to $10 \%$ ).

Under the influence of the KHPG, the temperature of distillation of $50 \%$ of gasoline decreases, which has positive effect on ICE warm-up intensity, stability of its perfor- mance at low crankshaft speeds, as well as acceleration time.

2. According to the results of the preliminary experimental studies, the temperature of medium gasoline fraction boil-off decreases significantly $(7-10 \%)$, which has positive effect on ICE performance. The decrease in the fuel distillation temperature indicates the increase in fuel-air mixture combustion intensity and efficiency as well as engine power.

3. Figures 3-4 present the results of DP studies showing that fuels of different quality $\left(K_{t}\right)$ have different values of dielectric permittivity under the KHPG influence with a different period of exposure. The decrease in dielectric permittivity of gasoline indicates the increase in fuel energy capacity.

4. Changes in engine performance parameters after KHPG action can occur both as a result of the integrated influence on fuel and engine systems and as a result of the influence on an individual factor which represents a primary cause of subsequent changes in parameters.

5. The recommendations for calibration of electronic engine control systems were developed. For purposes of full-scale studying of the KHPG influence on performance characteristics of fuels, it is necessary to perform further comprehensive studies. 


\section{References}

Denisov, A.A. (1998). Informacionnoe pole [Information field]. Saint Petersburg: Omega, p. 64. (in Russian)

Denisov, A.A. (1975). Teoreticheskie osnovy kibernetiki [Theoretical bases of cybernetics]. Leningrad: LPI, p. 40. (in Russian)

Hilliard, J., Springer, G. (1988). Toplivnaja jekonomichnost' avtomobilej s benzinovym dvigatelem [Fuel economy in road vehicles powered by spark ignition engines]. Moscow: Mashinostroyeniye, p. 142. (in Russian)

Makerle, Ju. (1987). Sovremennyi ekonomichnyi avtomobil [Modern economy car]. Moscow: Mashinostroyeniye, p.231. (in Russian)

Safiullin, R.N., Kerimov, M.A. (2014a). Teoreticheskie osnovy kompleksnoj optimizacii osnovnyh velichin i parametrov DVS ATS pri primenenii topliv razlichnogo kachestva DVS [Theoretic complex optimization basics of the main values and parameters of ICE (internal combustion engine) of AMV (automatic motor vehicles) at applying various quality fuels]. Vestnik Grazhdanskikh Inzhenerov [Bulletin of Civil Engineers], 4 (45), pp. 104-111. (in Russian)

Safiullin, R.N., Kerimov, M.A. (2014b). Metodika ocenki i realizacii kachestvennyh pokazatelej topliva na osnove issledovanija ego himmotologicheskih processov i svojstv [A technique of assesstment and realization of fuel quality indicators on the basis of researching its chemmotology processes and properties]. Vestnik Grazhdanskikh Inzhenerov [Bulletin of Civil Engineers], 3 (44), pp. 184-188. (in Russian)

Safiullin, R.N., Kerimov, M.A. (2014c). Razrabotka programmno-adaptivnyh sistem upravlenija po ocenke i realizacii racional'nyh kachestvennyh pokazatelej primenjaemyh topliv DVS [ Development of program and adaptive control systems for assessment and realization of rational quality indicators of applied ICE fuels]. Vestnik Grazhdanskikh Inzhenerov [Bulletin of Civil Engineers], 2 (43), pp. 139-146. (in Russian)

Safiullin, R.N., Kerimov, M.A. (2014d). Optimal'noe upravlenie DVS v diapazone jekspluatacionnyh rezhimov pri ispol'zovanii avtomatizirovannoj sistemy stendovyh ispytanij (ASSI) [Optimum control of ICE in the range of operational modes when using the ASSI]. Vestnik Grazhdanskikh Inzhenerov [Bulletin of Civil Engineers], 1 (42), pp. 121-126. (in Russian)

Safiullin, R.N. (2017). Data of the automated control system on the technical condition of the internal combustion engine of the vehicle. Utility Model Patent No. 174174 dd. 05.10.2017. (in Russian)

Safiullin, R.N., Kerimov, M.A. (2016). Sredstva fotovideofiksacii narushenij PDD: normativnoe regulirovanie i praktika primenenija: [Methods of photo-video recording of traffic violations: control and practical application]. Moscow: Direkt-Media, p.355. (in Russian) 